\title{
Front Matter: Volume 11710
}

, "Front Matter: Volume 11710," Proc. SPIE 11710, Practical Holography XXXV: Displays, Materials, and Applications, 1171001 (16 April 2021); doi: $10.1117 / 12.2596689$

SPIE. Event: SPIE OPTO, 2021, Online Only 


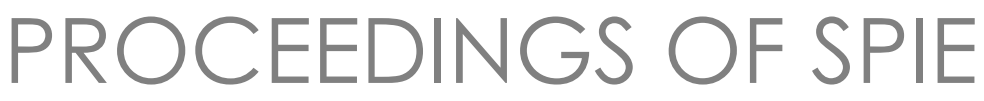

\title{
Practical Holography XXXV: Displays, Materials, and Applications
}

\author{
Hans I. Bjelkhagen \\ Seung-Hyun Lee \\ Editors
}

6-11 March 2021

Online Only, United States

Sponsored and Published by

SPIE

Volume 11710 
The papers in this volume were part of the technical conference cited on the cover and title page. Papers were selected and subject to review by the editors and conference program committee. Some conference presentations may not be available for publication. Additional papers and presentation recordings may be available online in the SPIE Digital Library at SPIEDigitalLibrary.org.

The papers reflect the work and thoughts of the authors and are published herein as submitted. The publisher is not responsible for the validity of the information or for any outcomes resulting from reliance thereon.

Please use the following format to cite material from these proceedings:

Author(s), "Title of Paper," in Practical Holography XXXV: Displays, Materials, and Applications, edited by Hans I. Bjelkhagen, Seung-Hyun Lee, Proceedings of SPIE Vol. 11710 (SPIE, Bellingham, WA, 2021) Seven-digit Article CID Number.

ISSN: 0277-786X

ISSN: 1996-756X (electronic)

ISBN: 9781510642553

ISBN: 9781510642560 (electronic)

Published by

SPIE

P.O. Box 10, Bellingham, Washington 98227-0010 USA

Telephone +1 3606763290 (Pacific Time) · Fax +1 3606471445

SPIE.org

Copyright (c) 2021, Society of Photo-Optical Instrumentation Engineers.

Copying of material in this book for internal or personal use, or for the internal or personal use of specific clients, beyond the fair use provisions granted by the U.S. Copyright Law is authorized by SPIE subject to payment of copying fees. The Transactional Reporting Service base fee for this volume is $\$ 21.00$ per article (or portion thereof), which should be paid directly to the Copyright Clearance Center (CCC), 222 Rosewood Drive, Danvers, MA 01923. Payment may also be made electronically through CCC Online at copyright.com. Other copying for republication, resale, advertising or promotion, or any form of systematic or multiple reproduction of any material in this book is prohibited except with permission in writing from the publisher. The CCC fee code is $0277-$ $786 \times / 21 / \$ 21.00$.

Printed in the United States of America by Curran Associates, Inc., under license from SPIE.

Publication of record for individual papers is online in the SPIE Digital Library.

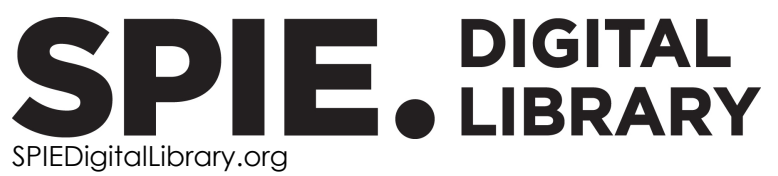

Paper Numbering: Proceedings of SPIE follow an e-First publication model. A unique citation identifier (CID) number is assigned to each article at the time of publication. Utilization of CIDs allows articles to be fully citable as soon as they are published online, and connects the same identifier to all online and print versions of the publication. SPIE uses a seven-digit CID article numbering system structured as follows:

- The first five digits correspond to the SPIE volume number.

- The last two digits indicate publication order within the volume using a Base 36 numbering system employing both numerals and letters. These two-number sets start with $00,01,02,03,04$, 05, 06, 07, 08, 09, OA, OB ... 0Z, followed by 10-1Z, 20-2Z, etc. The CID Number appears on each page of the manuscript. 


\section{Contents}

\section{MATERIALS AND PROCESSES}

$1171003 \quad$ Expanding the property profile of Bayfol $\mathrm{HX}^{\circledR}$ film towards NIR recording and ultra-high index modulation (Invited Paper) [1 1710-1]

1171005 Accommodation measurements of a holographic HUD using auto-refractor [11710-3]

$1171007 \quad$ C2 symmetric single-layered meta-atoms for asymmetric holography [11710-5]

1171008 One-step fabrication of surface relief dot-matrix holograms using supramolecular azopolymer thin films [11710-6]

\section{APPLICATIONS OF DISPLAY AND ART HOLOGRAPHY}

$11710 \mathrm{OA} \quad$ Evaluating autofocusing metrics for plankton holographic microscope image reconstruction [11710-8]

$11710 \mathrm{OB} \quad$ Digital hologram as a display optical system [11710-9]

$11710 \mathrm{OD}$ Holography in the visual arts practice: research and production [11710-11]

$117100 \mathrm{E} \quad$ Facilitating advancements in holographic techniques with dedicated high power laser combiners [11710-12]

\section{DIGITAL AND COMPUTER-GENERATED HOLOGRAPHY}

11710 OF CHIMERA and Denisyuk hologram: comparison and analysis (Invited Paper) [11710-13]

$11710 \mathrm{OH} \quad$ Real object-based holographic stereogram printing system using a high-resolution onedimensional moving camera array [11710-15]

$117100 \mathrm{l} \quad$ High-resolution hologram generation using wavefront recording plane method [11710-16]

11710 OK Resolution enhanced partial aperture imaging system using annular coded phase reflectors [11710-18]

$11710 \mathrm{OL} \quad$ Pixelated holographic reflector recording for retinal projection devices [11710-19] 


\section{POSTER SESSION}

$117100 \mathrm{M} 2 \mathrm{D} / 3 \mathrm{D}$ convertible holographic waveguide-type AR system using the liquid-crystalline microlens array with the electro-switching polarizer [11710-20] 